Western University

Scholarship@Western

Department of English Publications

English Department

Fall 2009

\title{
Building Utopia: Performance and the Fantasy of Urban Renewal in Contemporary Toronto
}

Laura Levin

York University

Kim Solga

The University of Western Ontario, ksolga@uwo.ca

Follow this and additional works at: https://ir.lib.uwo.ca/englishpub

Part of the English Language and Literature Commons, and the Theatre and Performance Studies Commons

Citation of this paper:

Levin, Laura and Solga, Kim, "Building Utopia: Performance and the Fantasy of Urban Renewal in Contemporary Toronto" (2009). Department of English Publications. 13.

https://ir.lib.uwo.ca/englishpub/13 
$<$ MT>Building Utopia

$<$ MSTPPerformance and the Fantasy of Urban Renewal in

Contemporary Toronto

<AU>Laura Levin and Kim Solga

<TEXT>When we set out to "stage" a city, whose vision of the city do we rehearse as "real" or "true"? Who benefits from that staging, and who pays the hidden costs? These questions are related to others that urban activists around the world have rightly asked for decades: Who benefits and who suffers in the name of aggressive, developer-driven urban regeneration projects? But they are also much more profound. They require, first, that we understand how such projects co-opt and redeploy the experiences of those they ultimately marginalize-the working class; low-profile, low-income arts and culture workers; innercity ethnic minorities, often refugees or newly arrived migrants-as they attempt to reimagine the contemporary worldclass city as fresh, hip, and, above all, "creative" (Florida 2002). Second, they demand that we interrogate how performers and activists who set their work up against these inherently conservative regeneration practices address-or fail to addressthe lives and experiences of those same citizens positioned, awkwardly, at both center and margin of what we will call the "creative city" script. 
Our case study in this exploration is the city we both call home, a city that has been, over the past five years, overwhelmed by the fantasy of creative redevelopment from both the top down and the bottom up. As official Toronto preens itself to take to the "world stage" in everything from sports and industry to arts and culture, it consistently markets an urban experience shaped by what Ric Knowles (2007) calls "diversity without difference": private, pay-to-enter venues masquerading as public space; complex webs of ethnic, religious, racial, and economic difference masquerading as a smiling multicultural mosaic. And yet, on the flip side of this official agenda, too many of the performer-activists working in counterpoint to the city's renewal efforts are busy generating their own versions of proprietary public space. They offer a provocative variation on the city's official themes, to be sure, but not a variation that comes close enough to thinking through how economic and social stratification subtly but insistently determine who gets to benefit from the dream of a utopic Toronto, and who gets shut out of the party.

$<$ A $>$ Nights in the Global City

<TEXT>Toronto's current cultural renaissance emerges as a blend of official discourses produced and disseminated by city hall, often in conjunction with both higher levels of government 
(provincial and federal) and private enterprise, positioned alongside a grassroots movement driven by a combination of environmental and cycling activists, public space advocates, and arts professionals. Despite their several differences, however, all of these groups share the stated desire to turn the city into a kind of urban utopia. The notion of "Torontopia" has its roots in the activist community ${ }^{i}$ but the overlap between those who work at city hall and those who work around and against it is considerable. Mayor David Miller and his like-minded leftwing counselors are known to be avid fans of the grassroots output, in particular the influential spacing magazine, which focuses on public space issues in Toronto. In fact, we can hardly speak of competing discourses of renewal; the official and the grassroots scripts are really variant conversations working in productive tension with one another. And, perhaps not surprisingly given the broadly performative pedigrees of so many of their players (politicians and artists alike), each of the city's "utopian" initiatives consistently employ explicitly theatrical forms of urban dramaturgy as they attempt to reconfigure traditional models of public space and trigger new forms of civic engagement.

The largest and most pervasive of these initiatives sees public institutions working with both government and corporate sponsors to promote Toronto as a global city of the future, a 
place built by and for Torontonians but whose most important spectator is the tourist. Official Toronto has eagerly leapt aboard the "creative city" bandwagon, adopting the ready-made "urban-development script" (Peck 2005:740) defined by economic development guru Richard Florida. Florida encourages planners to lure an increasingly powerful class of creative types (engineers, artists, musicians, designers, and knowledge professionals) to their cities, arguing that it is these creatives who hold the key to economic growth and effective urban branding. According to Florida-who was himself lured to Toronto in the summer of 2007 to take up the position of director of the University of Toronto's new Martin Prosperity Institute-members of the creative class look for a community with "abundant high-quality amenities and experiences, an openness to diversity of all kinds, and above all else the opportunity to validate their identities as creative people" (2002:218). In Toronto, even before Florida's near-messianic inperson arrival, the arenas of culture, heritage, and the arts already had become zones for Florida-style creative selfactualization, ground zero of the city's branding as it seeks the elusive "world class" label. As Toronto's The Creative City: A Workprint reminds artists, it is "not enough to generate new ideas" (2001:16); they must also consider how these ideas can be turned into shows that the world "wants to see" (18).ii 
The creative city script encourages urban actors to engage in extreme makeovers, and Toronto is following through with its own creative city mandate in two related ways. First, the city has invested heavily in the physical renovation of its most important cultural institutions, with dollars not only for bricks and mortar but also for a glimpse of the world's most visible "starchitects" and the performance of creative allure and cultural fashionability they trail in their wake. Contemporary Toronto is paying close attention to the theatricality of its facades, revamping what Erving Goffman would call its front stage areas (1959:107). The Art Gallery of Ontario (AGO) on Dundas street West has just reopened after a full-scale renovation completed by Frank Gehryiii; around the corner, Will Alsop recently reworked the Ontario College of Art and Design, building a stunning, black and white "flying" tabletop held aloft by brightly colored crayon legs. Most controversially, Daniel Libeskind brought literally massive change to the Royal Ontario Museum (ROM), smashing a multistory glass and aluminum crystal into the side of the old museum's Bloor street elevation. The napkin on which Libeskind reportedly sketched the original design is now the stuff of legend in Toronto, so much an icon of the creative city ethos and its parallel commitments to tourism and the arts that the infamous 
sketch has found its way on to the cocktail napkins in the museum's posh bar.

These architectural projects resonate with the hyperawareness of "spectacle and theatricality" that Paul Makeham finds in the creative city script, pointing to "a kind of urban planning which endorses not realism but façade, which models itself not on utilitarian ideas of traffic flow and pedestrian efficiency, but the stage set, the carnival, and the forum" (2005:157). The "creative city," then, is finally about the spectacle, rather than the performative production, of public space. The ROM offers an ideal example of this covert agenda. The museum renovation promised to remake the city for the city, creating, as Libeskind claims, a "bold reawakening" of civic life. Accordingly, a significant part of the crystal was originally meant to be transparent so that passersby could see exhibits from the street. This plan was jettisoned thanks to cost overruns and technical difficulties-a reminder that money is made at the ROM inside the gates, not at street level, and that the renovation is only "for the city" insofar as the museum is making money. Nevertheless, the ROM's official "Renaissance" in spring 2007 played up Libeskind's vision of the museum as a public place: museum officials engineered a one-night-only free "architectural opening" that turned the crystal into a stage set (a free concert took place on platforms at its base) and invited 
the public inside at no cost throughout the night and into the following day. The free opening, held in conjunction with the city's first annual Luminato festival, was the talk of the town, but it also neatly effaced the fact that it was many Torontonians' one chance to see the new ROM affordably, provided they were willing and able to line up through the night: regular adult admission is a steep CDN\$20.iv The AGO, the Gardiner Museum of Ceramic Art (also newly renovated and anchored, like both the ROM and the AGO, by an upscale restaurant), and the brand-new Four Seasons Centre for the Performing Arts are all similarly private venues that masquerade as open civic space; in each case, substantial disposable income as well as a fair amount of leisure time mark the price of access to local culture.

In tandem with these infrastructure investments, Toronto is also promoting the notion of city space as public creative space through regular cultural festivals such as the high-profile, Scotiabank-sponsored Nuit Blanche (an annual all-night celebration of art that promotes mass use of the streets and public transit after hours), the 2006 Humanitas festival (a celebration of ethnic diversity and global citizenship presented in concert with the city's "Live With culture" campaign), and Winterlicious and Summerlicious (seasonal opportunities for Torontonians to try elite restaurants for a fixed, comparatively low cost). Many of these festivals include a number of free 
events and use special transit routes and scheduling to encourage attendance from across income brackets; at least on the surface, they appear far more committed than the museums to enabling an inclusive engagement with art and "culture" in genuinely public space. Nevertheless, like "Renaissance ROM" and other infrastructure refurbishments, they have until now primarily generated the façade of a Toronto alive with culture rather than investing seriously and for the long term in the cultivation of local artistic labor.v

The Luminato festival, a largely private capital initiative supported with federal and provincial rather than civic government dollars, is perhaps the best example of a culturefest originally mapped on to Toronto's existing arts scene with an eye more to tourist promotion than to the support of local culture workers. Although Luminato's mission statement insists that it "embraces" collaborative projects among local, national, and international artists, and despite the promise that the 2009 edition of the festival will include more commissioned work and a "greater national presence" than ever before (Bradshaw 2009), the festival's framework resolutely remains corporate first, arts second (Janet Price, its most visible face, is CEO, not artistic director). Unabashedly deploying Florida's creative city vocabulary, Luminato bills itself as a weeklong event designed "not only [to] engage Torontonians with free shows but 
also [to] rebrand Toronto internationally" - and to "boost the whole province's [economic] fortunes" (Taylor 2008). The payoff has been huge. In 2008, after only one year of operation, Luminato won CDN\$22.5 million in provincial funding-money, journalist Kate Taylor astutely notes, made possible in large part by the political connections of its cofounders (highprofile business leaders Tony Gagliano and David Pecaut), and money that also represents a troubling politicization of the arts-granting process in Ontario. As Taylor points out, Luminato's windfall cut directly into the funds available for numerous other, lower-profile initiatives, including those funded by the Ontario Arts Council, an organization that serves up to 400 arts groups across the province with individual onetime grants. While the CEO of Toronto's Harbourfront Centre, Bill Boyle, told Taylor in May 2008 that Luminato will always prioritize its relationship with Toronto artists over its international ambitions, material evidence of this local-artsfirst attitude has until very recently been hard to find. vi Only a handful of original works were commissioned for the inaugural Luminato in 2007; for the most part, the heavily hyped event featured shows that were already running in the city. The festival was thus effectively laid on top of Toronto's existing performance and visual arts landscape, creating a parallel artas-culture show that encouraged residents not familiar with the 
convertdoc. input.658032.ajzHd 10

city's arts scene to imagine that all this work was new and, more importantly, was made possible by the festival and its intensively visible corporate sponsor, L'Oréal. Further, what was new seemed at times quite uncertain of its audience, of its locale, and of its relationship to the city's populations and their needs.

Back Home, a devised piece about aboriginal and migrant dispossession in contemporary Australia produced by Sydney's Urban Theatre Projects and cosponsored in Toronto by the Harbourfront New World Stage festival and Luminato 2007, offers a telling example of the latter's local disconnects. In its original Australian incarnation, Back Home begins with a bus tour through Sydney's Western suburbs; the tour ends in an anonymous backyard. The performance takes place there, set within the crushing intimacy of a "foreign" citizen's private space. The goal of this journey is to reorient spectators, to force them into collision with neighborhoods in their own city about which they may carry dangerous assumptions and a host of trace colonial anxieties. In Toronto, this context was lost. Worse: it was manipulated as show, turning dispossession into entertainment and reproducing colonial hierarchies within the framework of performance space. The modified bus tour raced spectators along Queen's Quay and the Gardiner Expressway, two of Toronto's least evocative roadways, while a young (white) 
convertdoc.input. 658032 .ajzHd 11

researcher read facts about Toronto's aboriginal history from a piece of paper. His script and our movement generated noticeable misses: often he would gesture behind the bus, or point far from the road, toward some space "out there" where we might locate Toronto's First Nations past. Meanwhile, the living neighborhoods through which we were driving-many of them struggling with poverty and creeping gentrification among their migrant populations-remained unstoried, unmarked. The tour's final destination was a makeshift backyard-backyard as theatre set, not backyard as invasive (and invaded) public-private space-on the grounds of the Centre for Addiction and Mental Health. The playing and viewing area was cut off from the rest of the CAMH grounds by a chain-link fence; uniformed security guards prevented passersby from "crashing" the show. As the sun set and lights came up in the residence rooms inside the Centre, the distance between "us" in the bleachers and the anonymous "them" in their hospital rooms-indeed, the distance between the story on the stage and the real stories of dispossession and loss in contemporary west end Toronto-could not have seemed greater. Was this performance really for Toronto and Torontonians? Or was Back Home imported on to the CAMH grounds to enact a hollow celebration of Toronto's civic responsibility in another example of the city on display for a proverbial 
elsewhere, for the global tourist empowered to define us as "world class"?

Luminato, like Nuit Blanche and the city's other annual culturefests, is now firmly embedded in Toronto's civic imaginary, and Torontonians appear by most accounts to be enjoying the party atmosphere that goes hand-in-hand with a broadscale commitment to the arts, whatever the underlying politics. But the creative city is, very clearly, not all fun and games: at its core, it is a place that embraces diversity only to obscure the inequities, ambivalences, and outright hostilities true difference brings. vii The creative city script is fueled by a "salad bar" approach to multiculturalism, promoted without a hint of irony on the Tourism Toronto website: "You know the feeling you get when you come across an amazing menu and want to order every dish? That's what it's like to be here" (2006). viii The creative city actively ignores the fact that ethnically, racially, and socially charged bodies can never "inhabit" public space in neutral ways; they always, as Harvey Young observes, "structure" that space by appearing out of place within it. The creative city script and the "diversity without difference" paradigm on which it depends intentionally obfuscate the social and racial markers that determine the contours of true public space. In the process they disavow the two questions central to the larger project of urban renewal: (1) How do we 
determine what it means to be "from" a city, to be able to claim place as coeval with self, to be able to feel "in place" and at home here, not just during Nuit Blanche or Renaissance ROM but on any ordinary day or night?; and (2) Who claims the right to be gatekeeper, to decide which residents qualify as "authentically" Torontonian and thus entitled to a share in the spoils?

$<$ A $>$ Toward a New Toronto

<TEXT>In the wake of Toronto's creative city branding and its often conservative politics, an alternative discourse of urban renewal has emerged, generated by a heterogeneous group of artists and activists who are working, sometimes individually and sometimes in ad-hoc or established organizations, to imagine a different kind of public space in and for Toronto.ix Propelled by an excitement about the city's future and a participatory aesthetic, these "Torontopians" seek to reactivate public space through a set of signature performance practices, all of which have certain features in common. They claim city space for citizens rather than for corporate interests; they are free and open to all; they privilege the use (and sometimes the guerrilla occupation) of public transit; they inhabit the streets at all hours of the day or night, turning them into safe zones for childlike play rather than dreaded places that provoke morbid, 
parental fear. Above all, they assert public ownership over civic space as a given and enact that ownership in peaceful protest against the large-scale usurpation of civic space by corporate interests.

Some of the most evocative and effective of these performance practices have come from the Toronto Public Space Committee (www.publicspace.ca). The TPSC is among the oldest and most well respected of the Torontopian organizations and is one of the very few whose mandate is overtly political. Founded by cycling activist David Meslin, this nonprofit group works diligently to protect Toronto's skyline, sidewalks, freeways, and airspace against privatization and ad-creep. To achieve its goals the TPSC uses a wide range of strategies, including directly political means (lobbying city hall and deputing in front of city council via its "Billboard Battalion" network) as well as performative interventions such as "guerrilla gardening" (in which residents are encouraged to plant and maintain gardens in neglected or abandoned spaces, often in defiance of "No Trespassing" signs). Demonstrating well the push-pull the TPSC and related groups feel toward the official renewal works sponsored by city hall, in 2005 Meslin launched City Idol, a political competition timed to culminate with the 2006 municipal election. City Idol encouraged would-be city counselors to express radical new ideas about the city's future while 
competing for the right to campaign as a bona fide, sponsored candidate in the election. Asking participants to make speeches and improvise in debates, City Idol provided a fresh kind of actor training: rehearsals for political office. These and other Torontopian performances are documented in countless photoblogs, in Spacing magazine, published quarterly since 2003, as well as in the Coach House essay collections uTOpia: Towards a New Toronto (McBride and Wilcox 2005), and GreenTOpia: Towards a Sustainable Toronto (Wilcox, Palassio, and Dovercourt 2007). In the pages of these texts you can read about ongoing community building, beautification, and environmental preservation projects and track the many ways the Torontopians "play" in public space. While few of these interventions match the political savvy of the TPSC, they share above all a belief in the socially liberating potential of creative play to transform the city from a place of alienation to a space for meaningful connection.

Torontopia is by no means a rebel movement; on the contrary, it has steadily been winning the accolades of Toronto's creative class, as well as of politicians and performance scholars. Fans celebrate the Torontopians as countercultural heroes for conjoining the spheres of theatre and the everyday and for asking spectators to engage with public space in unexpected ways. But amid the laudatory hype that 
almost universally greets this movement, questions as urgent as those ignored by the official creative city script have gone unasked. Which citizens, and which practices of urban citizenship, remain outside, even scorned by, the playful frame of civic celebration the Torontopians have laid atop the underused and underappreciated spaces of the city? How does their work implicitly sanction a particular, ultimately quite specific image of Toronto and what it means to be a Torontonian? If, as Jill Dolan argues in Utopia in Performance (2005), a utopia is an imagined space always partial and potentially exclusionary, what are the limits of Torontopia's alternative social imaginings, and what are some of the material consequences of the movement's failure to engage seriously those limits both in practice and in print?

Both of us identify as Torontonians, and we want to emphasize that we are both very committed to seeing the Torontopia movement flourish. We are also, however, committed to moving existing critical discourse about site-specific and urban dramaturgy in a more productively political direction-something we feel has been lacking in contemporary performance studies even as it thrives in fields like art history. As Miwon Kwon argues, the shift at the end of the 20th century away from sitespecific public art as an autonomous, multifaceted critique of the political, economic, and social tensions bisecting public 
space and toward that art as a public or community "good" (what Kwon, following Suzanne Lacy, calls "new genre public art") enabled a coercive, if often unintentional, censorship of those individuals and practices that could not easily be integrated into the community's sense of itself and its public goals (Kwon 2004:56-99; see also Lacy 1995). New genre public art, as Kwon notes, has a long history in the making of "socially responsible and ethically sound public art" (Kwon 2004:82), but it also risks totalizing both the idea of "community" and the equally fraught notion of "the public good" on which it rests. The fractured and diverse Torontopian activities that mark our city's contemporary cultural landscape share the goal of civic disruption in the name of community building; they thus qualify as examples of "new genre public art" and, we believe, require a sustained critique of their methods, outcomes, and potential blindspots in order to move forward productively.

$<$ A $>$ The "Walking Creature" and the "Talking Creature" $<$ B $>$ Fissures in the Torontopian Script $<$ TEXT>As we have noted, many of the spaces marketed as public and universally accessible by the creative city are actually proprietary: they embed various restrictions to access that are downplayed in their promotion. The Torontopians are helpfully critical of this fantasy of "private-public" space, and they use 
convertdoc. input. 658032 .ajzHd 18

their guerrilla-style site-specific performance practices to open up the city to the hidden stories and spaces the creative city rhetoric so easily ignores. And yet, much of what the Torontopians have thus far produced under the banner of reinvigorated public spacing is also a fantasy. It erects its own (quite significant) barriers to access, built upon unacknowledged assumptions about which spaces and citizens count and which don't-all well disguised by the discourses of fun, play, discovery, and political progressiveness that surround the projects themselves. These barriers are in many ways more meddlesome than those set up by mainstream creative city initiatives because they are not foremost about money, but hinge instead on class and gender issues that the Torontopians too often dismiss as insignificant to their agenda. Some of these issues are spotlighted by dramaturgical problems we've encountered in two different genres of Torontopian performance: the "walking creature" and the "talking creature." The "walking creature" refers to a host of practices that attempt to perform an alternative urban script by walking the city counterdiscursively. These practices are among Torontopia's most popular: they include the [murmur] project, which plants recordings about pedestrian-level urban life around the city to be accessed by passersby on their cell phones; the Toronto Psychogeography Society, which hosts walks all over the city, 
both downtown and in the suburbs, for small and large numbers; "hidden Toronto" tours; parkour activities; and various forms of urban gaming. The dominant critical frame that the walkers apply to their labor is that of flâneurie, tracing a history of performance practices from the surrealists to Walter Benjamin, to the situationists, to Michel de Certeau. Flâneurie, of course, is not a politically neutral practice (as some urban performance enthusiasts tend to forget); it is based on a host of often-invisible social privileges. In order to be able to walk the city differently, one needs at the very least a tremendous amount of spare time, if not money. Flâneurie is, at the very least, no less a fantasy of civic ownership and control than that theorized by de Certeau as he famously gazed down on Manhattan from the top of the World Trade Center (1984). Performed at street level by an individual who then reports his findings to like-minded friends, family, and readers, flâneurie obscures both the enabling conditions that drive its urban wanderings and the political conflict those wanderings encode. "Walking in the city" assumes unrestricted physical access, but for whom is walking differently not a simple option because walking in even the most conventional ways is a fraught endeavor? Kwon again: $<\mathrm{EX}>[\mathrm{T}]$ he paradigm of nomadic selves and sites may be a glamorization of the trickster ethos that is in fact a reprisal 
of the ideology of "freedom of choice"-the choice to forget, the choice to reinvent, the choice to fictionalize, the choice to "belong" anywhere, everywhere, and nowhere. This choice, of course, does not belong to everyone equally. (2004:165) <TEXT1>For many citizens, wandering the city can be a tall order indeed: those whose job or family commitments don't permit weeknight, or even weekend, excursions; those who live in the suburbs or exurbs without a car or without convenient links to public transit; those with physical disabilities; the homeless or dispossessed; women. Doreen Massey, writing about gendered access to public space in Benjamin's Paris, argues: "the notion of a flâneuse is impossible precisely because of the one-wayness and the directionality of the gaze. Flâneurs observed others; they were not observed themselves" (1994:234). Scholars of women in urban space have repeatedly noted that the price of a woman's freedom to walk was, at the beginning of the modern period, a quite literal one: women were permitted to appear in public to shop or to sell; otherwise, their wanderings risked crossing a dangerous border, and risked male violence in retribution." Walking in the city might seem substantially easier for women today, but the risks of being watched uncomfortably or even threatened physically remain. In an essay posted on the Toronto Psychogeography Society website and originally published in Spacing magazine, Anna Bowness (2004) makes this very 
convertdoc.input. 658032 . ajzHd 21

observation-but only in passing. Her small reference to the "violence" and "fear" that might attend a woman attempting the role of flâneur remains the only reference to gendered problems of access-and one of the very few references to problems of access of any kind-that we have found in the published materials on walking creature practices in contemporary Toronto. $<$ TEXT>Perhaps more pervasive than gendered barriers, however, are the invisible social barriers that shape the walking creature in its most prominent incarnations. The [murmur] project appears on the surface to be fully public: all you need to engage with its narratives is a mobile phone and a few extra minutes on the way home from work or school. But in practice [murmur] can be an expensive undertaking, as Laura Levin (this article's coauthor) discovered when she took a class of her York University students downtown to experience the project. Many of Levin's students owned phones with significant restrictions on daytime minutes, forcing them to pay an "out of plan" fee each time they dialed one of the numbers on the [murmur] route; for some, the bill for calling up [murmur] amounted to more than they might pay for a comparable night at the theatre. The [murmur] project, the students quickly discovered, assumes an ideal spectator: a downtown dweller with a "city" calling plan to match her hip urban lifestyle. 
convertdoc.input. 658032 .ajzHd 22

The challenges Levin's students encountered with [murmur] raise one of the core questions we aim at this kind of work: For whom is it made, and who benefits from its psychic remapping of Toronto? More significantly, for a class critique: What is its relationship to those who already occupy the "hidden" or "invisible" city-the homeless and those who work on the streets? Diplomatic Immunities: The End (2007), a devised theatre piece by Mammalian Diving Reflex, offers a glimpse of Torontopia's engagement with truly grassroots street culture. As part of their advance preparation for this show, Mammalian Diving Reflex performers interviewed a sex worker from the Bloor and Lansdowne area in west end Toronto. While the questions they asked her were not markedly different from those they asked other interviewees, the tenor of the interview, and the documentarystyle framing of the subject by the camera, all worked to index the sex worker as a metaphor for her (supposedly) rough-andtumble neighborhood. The problem was not that MDR performers feared this woman: their spoken intention was to explode conventional middle-class fears of street culture. Rather, the problem was more insidious: their questions, and their camera, turned them easily into cultural tourists and the sex worker in their crosshairs into a piece of ethnographic research they could then handily transport home to their audiences. Like other "exotic" objects of the walking gaze, this woman was a prop, not 
convertdoc. input. 658032 .ajzHd 23

a player, in Mammalian Diving Reflex's self-edifying excursion into the urban outlands.

The walking creature's claim to open access obscures the covert barriers that determine who is "free" to participate; it also hides a troublingly elitist class politics. The flâneur is a detached figure; his concern is primarily for the city as an aesthetic entity, not for those who appear within the landscape (except as intellectual, perhaps erotic, objects of his gaze). He walks to revive the hidden city; the city's bodies are folded into his apparently progressive watching (just as Mammalian Diving Reflex folded the Bloor and Lansdowne sex worker into their progressive politics of fear-no-street-walker). But as the modern flâneur walks away, what traces does he leave behind? One of the characteristics of contemporary Toronto flâneurie is its insistence that anyone can walk the city, anytime, but within this framework lies an unspoken alternative: that not to walk the city is to fail to appreciate the city properly, to fail to understand that remaking Toronto as an urban utopia requires a commitment from every citizen to learn to navigate the city better, more progressively. Not to walk the city, in other words, is to fail the city politically.xi On this new map, those who rely on cars for work or food shopping register as social dinosaurs rather than as citizens with vehicle-specific needs (Glouberman 2005:127-28); those who rely on cars as a result of 
physical or other disabilities do not register at all. By laying these ideological distinctions subtly atop the city's existing grid, the walking creature erects a political barrier between those who care enough to "do" Toronto differently and those who need to be saved by the culture warriors from their mundane, artless lives.

The class division between the creative haves and have-nots is nowhere more in evidence than in Toronto's Kensington Market, the city's most iconic Boho village. In 2004, activists and business owners in the Market established "Pedestrian Sundays," an initiative that turned Kensington into a street fair once a week in an attempt to prove that the city was more fun, and more socially productive, without cars. In his thoughtful analysis of PS Kensington, Misha Glouberman describes how the initiative's supporters promoted themselves as inherently progressive citizen-activists while dismissing the logistical concerns of many of the Market's shopkeepers. Glouberman points out that Pedestrian Sundays offered a business boost for café and bistro owners, but their effects on the grocery businesses that form the Market's backbone were "disastrous," chasing away customers who relied on cars for grocery transport (2005:128). Just as [murmur] subtly implies an ideal, hip local listenership, "[t]he utopian vision of the Market imagined a population of healthy young people with the kinds of lives that don't require cars," 
excluding in the process the area's older, traditional users as less creative, less committed, lesser-class urbanites (2005:128). Far from realizing a fresh and inclusive neighborhood space, in Kensington Market pedestrianization threatens to mythologize the "community" as "countercultural," easily skipping over-and in some cases discounting altogetherthe diverse histories and contributions of existing residents both to that community and to the Market's larger public good(s). It similarly risks homogenizing that community as being opposed to a certain kind of capital ("canned foods and toilet paper" [2005:129])-that which area activists deem too commercial or not trendy enough.

In the walking creature narrative, primarily male, primarily young, primarily able-bodied culture workers replace the maligned barons of capital, but the underclass remains largely the same; a handful walk the city differently, but the majority live on, unchanged. The "talking creature," meanwhile, faces related problems: under the banner of intimate interaction, it reproduces existing models of difference. We borrow the term "talking creature" from Darren O'Donnell (2006), founder of performance company Mammalian Diving Reflex; the talking creature forms part of a larger model of urban engagement that O'Donnell calls "social acupuncture." O'Donnell is actively resistant to many of the Torontopian practices that 
convertdoc. input. 658032 .ajzHd 26

fly in and around the creative city orbit. He argues that too much of this work has either been co-opted by the very machines of capital it set out to jam, or, more troublingly, has fallen prey to an aestheticization that lacks any real sense of politics. "I worry that we prefer fun and whimsy to rigorous social engagement," O'Donnell writes, arguing that we need to raise the "stakes" of our urban performance practices, "to start engaging with unease and discomfort" (2006:23) in order for a more inclusive map of the city to emerge.

The talking creature O'Donnell proposes includes work as diverse as "Free Dance Lessons" (originated by Paige Gratland and Day Milman and offered nightly as part of Luminato 2008), The Toronto Public Space Committee's "City Idol" competition, and the Trampoline Hall lecture series curated by Sheila Heti. The program's mandate is simple: to reframe human engagement with the city by reframing our engagement with one another, slowly changing our relationships to the strangers who use the city alongside us. In some ways, the talking creature goes a step beyond the implicit voyeurism of the walking creature by insisting upon a different kind of urban intersubjectivity; it also offers welcome resistance to the intensely heteronormative, fun-for-the-whole-family message of large-scale "Live With Culture" events like Renaissance ROM. During Nuit Blanche on 29 September 2007, for example, O'Donnell hosted Slow Dance with 
convertdoc. input. 658032 .ajzHd 27

Teacher, a performance intervention at the Hart House Great Hall on the University of Toronto campus. Slow Dance was designed to foreground, interrogate, and reframe what $\mathrm{O}^{\prime}$ Donnell describes as "that exciting and forbidden desire" that characterizes studentteacher interactions, certainly in North American cultural mythology if not always in practice (in Houston 2008:102). While Slow Dance purposefully rehearsed many of the self-conscious anxieties that circumscribe young peoples' (and, indeed, older peoples'!) experiences of their bodies in awkward social situations (2008:105), it also offered an opportunity, at least in theory, to push past those anxieties and take personal risks, as participants danced with strangers in an intimate way (arms around waists, heads on shoulders) often reserved for interactions with loved ones. Performances like Slow Dance suggest the promise of O'Donnell's talking creature, its potential to enact, and to probe the limits of, the alternative family structures that operate in the city as essential support networks for those who have been displaced from the communities in which they grew up. In this sense, the talking creature implies inclusivity and perhaps even a sense of security for the very people inadvertently left behind by the walking creature model.

This is the promise. In practice, the talking creature too often relies on false intimacy and a fetishized authenticity to 
convertdoc. input. 658032 .ajzHd 28

produce interactions between participants that are touted as edgy and risky but on closer inspection turn out to be at best quite conservative. Diplomatic Immunities: The End, Mammalian Diving Reflex's attempt to transport some of O'Donnell's streetlevel talking creature interactions back into the theatre, showcases the problems with which this model struggles. While O'Donnell has admitted that recreating spontaneous interactions on the stage is in some senses impossible (2006:86), he aims in the Diplomatic Immunities seriesxii to resolve the issue by "creat[ing] an entertainment event that [is] as close as possible to simply hanging out" (87). Diplomatic Immunities: The End relies for currency on this sense of "real" people onstage in constant interaction with "real" folks in the audience: although they are onstage and we in our seats, the lights and video cameras focus on us throughout the performance, while the performers, styled as "research artists," zero in on individual audience members in order to ask them questions. Twice during the show the performers invite spectators onstage and direct the remainder of the audience to ask them questions; no frame or limit is placed on what these questions might be.

Two significant dramaturgical problems hamper Diplomatic Immunities' claims to urban activism. First, the performers insist that this is not theatre, eliding their own representational strategies and the obviously rehearsed quality 
of their interactions among one another and with us. Not only does the show refuse to admit that performance is a core part of everyday human interaction both onstage and off, but its obsessive resistance to representation, along with its insatiable demand for "authentic" audience responses, creates a coercive atmosphere within the audience proper. As Glouberman (also a "research artist" in the Diplomatic Immunities cast) writes, "Part of the force of a utopian idea is that it can make you feel ashamed to disagree" (2005:127). In Diplomatic Immunities, every audience member competes with every other, and with the performers, to appear as authentic, natural, and unrehearsed as possible; rather than encouraging our genuine interaction or promoting an interrogation of what is at stake in attempting to generate "genuine" human interaction in the first place, the show demands our virtuosity even as "performance" becomes the 500-pound gorilla in the room.

More troubling, though, is the way in which Diplomatic Immunities invests in a temporary and ultimately hollow intimacy, a false sense of collective care that preempts any genuine acts of ethical witness between and among performers and audience members. O'Donnell's goal is to produce a sense of shared community in the vein of Dolan's "utopian performative," but the question of who belongs within and who remains outside the bounds of this imagined community hangs in the air without 
convertdoc.input.658032.ajzHd 30

ever being properly examined. (This is the same problem, of course, that plagued the production's video interview with the Bloor and Lansdowne sex worker.) The night we saw the show together, we found ourselves wondering: Does ethnographically introducing us to the "other" break down boundaries between discrete communities, or does it simply reinforce the surface spectacles of difference that are the basis of so many events hosted by official "multicultural" Toronto? The questions performers asked of audience members during the show were often painfully generic ("What is your greatest fear?"), and when audience members questioned one another the results were either banal ("Why would you lie to your mom?") or prying ("What color is your underwear?"). The cast reminded audience members that they could refuse to answer any question with which they were uncomfortable (one of the hallmarks of o'Donnell's talking creature practice both onstage and in the street), but in the moment of performance this proved a superficial disclaimer. The peer pressure in the theatre was palpable: we at once craved and feared being called upon. Once on the spot, the refusal to respond seemed to bring with it a risk of greater humiliation. Following Claire Bishop (2004), O'Donnell calls the $Q \& A$ model on which Diplomatic Immunities is built a "dialogical" intervention (2006:29); he argues that this model encourages the appearance of class, racial, and gender difference within the event frame, 
convertdoc.input. 658032 .ajzHd 31

demanding that participants take responsibility for the uncomfortable information their questions may bring to light (32). At Diplomatic Immunities, however, the friction real difference can produce seemed rarely in evidence, and the performers carefully managed any deviations from their invisible script.

Ironically, this management had the opposite effect of Dolan's utopian performative. The performers failed to generate a sense of shared responsibility for the stories they were caching because they seemed unaware of the kind of commitments that charge the space between actor and spectator in performance, and unaware too of their own power to control and manipulate those commitments. On the night we attended, during the first sequence in which an audience member (a man who, by process of elimination, had been determined to be "the most frightened person in the room") was invited onto the stage, another spectator managed to interrupt-and expose-the show's carefully contrived authenticity. A theatre student (as we soon learned), he raised his hand to ask the man onstage if he wanted company; he then came down to join him. This young student was obviously very eager to be part of the show, for professional as well as personal reasons: while onstage he told the story of auditioning for a popular Toronto director and even performed his impression of the director watching him in a moment that 
convertdoc.input. 658032 .ajzHd 32

seemed oddly, and fittingly, like he was at the same time auditioning for $O^{\prime}$ Donnell and his cast by "playing himself" in their show. He then told the audience, "This is me. This is who I am," spinning his improv, with all sincerity, as a form of authentic selfhood-a trick anyone who has been to theatre school will recognize as a resolutely performative gesture designed to secure professional status. Ironically, this sequence energized the room in a way few of the other moments in the show managed to do. Audience members, finally faced with the productive tension between performance as artistic labor and spectatorship as social responsibility on which all theatre pivots, were eager to hear, and to laugh at, the young man's story-to see an actor occupy the stage, and to occupy it willingly. Rather than taking their cue from this opportunity, however, o'Donnell's performers quickly shut the young man down, anxiously denying the links between their show and the world of rehearsed theatre he had inadvertently established.

In a talkback discussion at the 2008 Canadian Association for Theatre Research conference in Vancouver, Andrew Houston suggested that the problems we identify with Diplomatic Immunities: The End can in large part be attributed to the venue in which it was presented: a working theatre. Social acupuncture, he argued, tends to work more effectively on the street-in, for example, Slow Dance with Teacher or O'Donnell's 
convertdoc.input.658032.ajzHd 33

trademark Haircuts by Children (touring since 2006)-where spectatorial response can rarely be so easily managed.xii While we concede that Diplomatic Immunities: The End provides in many ways a unique and to some extent erroneous snapshot of Mammalian Diving Reflex's larger body of work, we also want to insist on the ways in which it telescopes the ethical minefield in which that work always circulates. The problems we encountered in the theatre with Diplomatic Immunities are no less prevalent on the street. In fact, in the apparently "authentic" space outside the theatre, many of those problems are amplified. Because MDR always claim that they are not making performance, but are rather facilitating encounters in "real" space, they always implicitly deny the specific codes of ethical conduct that must link creator and spectator, and spectators one with another. A performance like Slow Dance with Teacher, for example, encodes a specific kind of cultural transaction for which Mammalian Diving Reflex cannot fully account. Part of a group of physically intimate experiments with strangers in public space initiated by MDR (see O'Donnell 2006:68-72) the event asks participants to assume personal, embodied risk-risk that is implicitly greater for women than for men, and that may be greater yet for members of the LGBTQ community. Even more than Diplomatic Immunities, Slow Dance with Teacher thus invites the question central to the critique we undertake here: Who 
benefits? While the risk embedded in Slow Dance is understood to be part of what charges it with political vibrancy for all parties involved (see Houston 2008), because the event never makes clear the level of responsibility the organizers and volunteer "performers" are willing to take for its ad-hoc participants, this risk also limits in a very real way who can take part, and how. Given that these urban experiments are explicitly set up to ridicule bourgeois concerns for personal safety, and, in O'Donnell's words, to "[create] a clear divide between those who cho[o]se to participate and those who [don't]" (2006:71), the experience of "authentic" discomfort can be extremely hard for participants (or for those who choose actively not to participate) to articulate. The talking creature's premise is that our culture of fear undermines agency in urban spaces, yet this model trades one form of socially enforced control for another. In the spaces of "play" constructed by MDR, failure to conform to the ideal of pleasurable and "unfettered" social interaction incurs ridicule, discomfort, and ostracization, the very tools that are employed to enforce more recognizable forms of authority in the larger public sphere.

Social acupuncture is an "at your own risk" activity; it implies in its rhetoric and its assumptions about audience agency that taking a risk is a fairly straightforward matter of 
convertdoc. input. 658032 .ajzHd 35

leaping beyond one's own inhibitions. Risk taking, of course, does not take place in a vacuum and does not always function in counterpoint to an irrational culture of fear (which itself often stifles and inhibits risk-taking); a variety of complex lived experiences influence the meanings of intimate social interaction for any given subject. As a theory of urban innovation, then, $\mathrm{MDR}^{\prime}$ s version of the talking creature neatly sidesteps its creators' own social and ethical positionings, as well as their assumptions about the neutrality of public space, even as it frames participation in its signature events as a matter of personal courage.

Toronto's official creative city script relies for its potency on the illusion of widely available public space and the fantasy of a city for all; simultaneously, the city's urban performance activists seek to jam these contrivances and to resituate public space as genuinely for all-that is, for "real" people rather than corporate power players. And yet the question of who qualifies as "real" in this other newly imagined, phantasmatically inclusive community hovers on the edges of Torontopian playfulness, provoking a series of questions about the costs of material as well as cultural growth, and about who Torontopia, like Toronto's official "Live With Culture" story, leaves behind. So how, then, do we avoid rehearsing more of the same in urban performance activism? Where are the practices that 
will generate the kinds of disquieting encounters with difference that we need in order to spark real shifts in the way we understand the shape of our city and the creative work of its many inhabitants? As we approach our own ending, we are all too aware that performance criticism embeds its own, unspoken privileges: we have been privileged to pull this work apart, but have not yet taken upon ourselves the challenge, the struggle, the responsibility to create an alternative. In closing, then, we would like to point in just one possible new direction and call for performances that take up the noncelebratory: that focus on what is frustrating, fraught, even at times genuinely dangerous about being in the city; that refuse to glorify the urban playground and take note, instead, of those for whom the city is not simply about play, but is also about work, about safety issues, and about struggle. Kwon calls this work "collective artistic praxis"; it makes a virtue of opposition, builds art from real conflict and collision rather than insisting on a consensus over what constitutes community values, morally, aesthetically, and politically (2004:154). This work does not mean asking superficial questions of one another; rather, it means asking difficult, at times truly upsetting, questions of ourselves and of our work. 
<FN>i. Jason McBride and Alana Wilcox's popular 2005 anthology uTOpia: Towards a New Toronto, offers a wealth of history about and social context for the now-ubiquitous term "Torontopia." ii. For a broader discussion of performance and creative city politics, see Levin (2007).

iii. Gehry grew up in the Grange neighborhood that surrounds the AGO, a fact that allowed the gallery to trumpet his natural fit for the renovation, never mind the obvious international power of his brand. Gehry was not just swooping in to lend his allure to the city, in other words; the gallery and the media could image him as a hometown boy, literally embodying Toronto's world-class status and de facto creative city power. iv. This seems to be a trend in museum post-renovation reopenings: when MoMA reopened in New York a few years ago, there was much controversy over the new admission price of US\$20. The ROM's website (www.rom.on.ca) prominently advertises its "half price" Friday nights (from 4:30 PM to 9:30 PM), but conceals among the fine print the fact that every Wednesday, from 4:30 PM to 5:30 PM, admission to the permanent galleries is (briefly) free.

v. For a critique of the relationship among the art, artists, and communities that comprised the 2008 edition of Nuit Blanche, see Levin and Solga (2009). 
vi. In september 2008 Luminato committed CDN\$50,000 to a new grant program, Incubate, developed by the festival in conjunction with the Toronto Arts Council. The one-year pilot project, valued at a total of CDN\$100,000, offers musical arts workers the opportunity to apply for one-time awards of up to CDN\$10,000. This is a welcome development, and suggests that future Luminato events may do better at integrating lowerprofile local artists.

vii. Shortly after arriving in town, Richard Florida inadvertently provided a great example of how central "diversity without difference" is to his "creative city" script. Followed by Globe and Mail reporter Peter Scowen to the city's Kensington Market neighborhood, a zone in which older immigrants, young professionals, students, artists, potheads, and environmental activists-not to mention tourists-jostle cheek-by-jowl, Florida remarked on the unique flavor of a place located at "the intersection of immigrant and hippie." Asked to comment on the challenge of preserving such a mixed-use enclave, Florida argued that "the uses can change, the character of a storefront can change, Italians can replace Jews, Jews can replace Indians, a hippie can replace a Chinese entrepreneur, an upscale clothing shop can replace that kind of guitar shop, [but] the tragedy is when the neighborhood is cleared-when they come in with the 
federal bulldozers and just say, 'We're going to knock it down and put in high-rise condominium towers"" (2007). Florida's remarks betrayed not only his ignorance of the place in which he found himself, but also his failure to appreciate the serious matter ethnic and class differences make behind the pleasurable façade of diversity in the creative city. Not only are parts of Kensington Market already gentrified, in some cases at the expense of longtime shop owners, but his conflation of cultures (Italian/Indian/Chinese/Jew) and classes (upscale clothing shop/downmarket guitar store) bespoke his failure to appreciate the local tensions that shape the Market today. viii. Luminato's mission statement offers a similarly banal take on "diversity": "Toronto is one of the most multicultural cities in the world. Luminato embraces and celebrates the cultural diversity of the city, and recognizes that creativity flourishes when cultures join together in a spirit of tolerance and respect" (Luminato 2008). ix. Toronto has an urban play movement that is diverse and ever changing; it encompasses everything from local walking groups, lecture series, and community gardening organizations to parkouristes [see "Parkour or l'art du déplacement: A Kinetic Urban Utopia" by Jimena Ortuzar in this issue of TDR], urban explorers (such as the late cult hero Ninjalicious 
[www.infiltration.org]), and large-scale social events hosted by well-established play groups. We can cite here only some of its most visible representatives. In addition to the Toronto Public Space Committee and the editorial and writing staff of Spacing magazine, see the work of Shawn Micallef, a Spacing editor, author of its regular "Toronto Flâneur" column, head of the Toronto Psychogeography Society (www.psychogeography.ca/blog), and founding creator of the [murmur] public performance project, now in seven cities (http://murmurtoronto.ca). Also worthy of note: the Trampoline Hall lecture series (www.trampolinehall.net), a favorite among the city's young culturati, and Newmindspace (www.newmindspace.com), defined as "interactive public art, creative cultural interventions and urban bliss dissemination" by founders Lori Kufner and Kevin Bracken .

x. In addition to Massey (1994), see Friedberg (1993) and Rabinovitz (1998) . xi. For an excellent example of overtly polemical writing about the relationship between political progressiveness and walking the city, see Wrights and Sites (2006). xii. Mammalian Diving Reflex has taken its "research" work for Diplomatic Immunities-part of its larger project of "social acupuncture"-around the world, and in late 2007 produced a show 
in Lahore called Diplomatic Immunities: The Scars of Pakistan. Diplomatic Immunities: The End remains the company's flagship production of this work. xiii. Haircuts by Children, for example, is simply what the title says: an opportunity for adults to have their hair cut, in a supervised environment, by children with only minimal prior training

\section{$<$ REF $>$ References}

Bishop, Claire. 2004. "Antagonism and Relational Aesthetics." October 100:51-79.

Bowness, Anna. 2004. "Walking and literature make sense together." Spacing 2: 39. Reprinted at wWw.psychogeography.ca/pdf/anna.pdf (20 June 2007). Bradshaw, James. 2009. "More commissions, greater national presence at Luminato." The Globe and Mail, 17 February:R2. Certeau, Michel de. 1984. "Walking in the City." In The Practice of Everyday Life, 91-110. Berkeley: University of California Press.

City of Toronto. 2001. The Creative City: A Workprint. Official Website of the City of Toronto. Toronto Culture Division. www.toronto.ca/culture/brochures/brochure_culture_workprint.pdf (18 September 2008). 
Dolan, Jill. 2005. Utopia in Performance: Finding Hope at the Theater. Ann Arbor: University of Michigan Press. Florida, Richard. 2002. The Rise of the Creative Class... And How It's Transforming Work, Leisure, \& Everyday Life. New York: Basic Books. Friedberg, Anne. 1993. Window Shopping: Cinema and the Postmodern. Berkeley: University of California Press. Glouberman, Misha. 2005. "No Place Like Kensington." In uTopia: Towards a New Toronto, eds. Jason McBride and Alana Wilcox, 126130. Toronto: Coach House Press.

Goffman, Erving. 1959. The Presentation of Self in Everyday Life. New York: Doubleday/Anchor. Houston, Andy. 2008. "Slow Dance with Teacher: Innocence After Experience." Canadian Theatre Review 133:102-06. Knowles, Ric. 2007. Respondent. "Building Utopia," by Laura Levin and Kim Solga. ATHE 2007 Annual Conference, New Orleans, LA. 28 July. Kwon, Miwon. 2004. One Place After Another: Site-Specific Art and Locational Identity. Cambridge: MIT Press. Lacy, Suzanne, ed. 1995. Mapping the Terrain: New Genre Public Art. Seattle: Bay Press.

Levin, Laura. 2007. "To Live With Culture: Torontopia and the Urban Creativity Script." In Space and the Geographies of 
Canadian Theatre, ed. Michael McKinnie, 201-17. Toronto: Playwrights Canada Press. Levin, Laura, and Kim Solga. 2009. "Zombies in Condoland." Canadian Theatre Review 138:48-52. Libeskind, Daniel. n.d. "Concept Sketch of the ROM." Royal Ontario Museum. www.rom.on.ca/crystal/napkin.php?view=3 (20 June $2007)$

Luminato. 2008. "About Luminato." wWw.luminato.com/festival/eng/mainabout.php (3 April 2009). Makeham, Paul. 2005. "Performing the City." Theatre Research International 30, 2: 150-60. Mammalian Diving Reflex. 2007. Diplomatic Immunities: The End. Conceived and dir. Darren O'Donnell. Performed by Mammalian Diving Reflex at Buddies in Bad Times Theatre, Toronto. 24 February • Massey, Doreen. 1994. Space, Place, and Gender. Minneapolis: University of Minnesota Press. McBride, Jason, and Alana Wilcox, eds. 2005. uTOpia: Towards a New Toronto. Toronto: Coach House Press. O'Donnell, Darren. 2006. Social Acupuncture: A Guide to Suicide, Performance and Utopia. Toronto: Coach House Books. Peck, James. 2005. "Struggling with the Creative Class." International Journal of Urban and Regional Research 29, 4:74070 . 
Rabinovitz, Lauren. 1998. For the Love of Pleasure: Women, Movies, and Culture in Turn-of-the-Century Chicago. New Brunswick: Rutgers University Press. Scowen, Peter. 2007. "At the Intersection of Immigrant and Hippie." Globe and Mail, 10 November:M3. Taylor, Kate. 2008. "From Zero to \$22.5-million in 2 Years." The Globe and Mail, 24 May:R12.

Toronto Public Space Committee. n.d. (www.publicspace.ca) . (20 June 2007).

Tourism Toronto. 2006. "Toronto 101: Why Toronto?" WwW. torontotourism.com/Visitor/Toronto101/WhyToronto.htm (20 June 2007)

Urban Theatre Projects. 2007. Back Home. Dir. Alicia Talbot. Prod. Urban Theatre Projects (Sydney, Australia), Harbourfront New World Stage, and the Luminato Festival. Centre for Addiction and Mental Health, Toronto. 9 June.

Wilcox, Alana, Christina Palassio, and Johnny Dovercourt, eds. 2007. Greentopia: Towards a Sustainable Toronto. Toronto: Coach House Press.

Wrights \& Sites. 2006. "A Manifesto for a New Walking Culture: 'Dealing with the City.'" Performance Research 11, 2:115-22. Young, Harvey. 2007. Post-panel discussion. "Fresh Print Series 3: Space." ATHE 2007 Annual Conference. New Orleans, LA. 29 July 
<BIO>Laura Levin is Assistant Professor of Theatre at York University. Her research, which focuses on performance, identity, and space, appears in several edited volumes, including Space and the Geographies of Theatre (Playwrights Canada, 2007) and Performance and the City (Palgrave, 2009). She is Associate Editor of the Canadian Theatre Review and Editor of a number of collections: an issue of Theatre Research in Canada on "Space and Subjectivity in Performance"; an issue of Canadian Theatre Review on "Performance Art"; Conversations Across the Border, with performance artist Guillermo Gómez-Peña (Seagull Press, forthcoming); and Theatre in Toronto (Playwrights Canada Press, forthcoming). <BIO>Kim Solga is Assistant Professor of English at the University of Western Ontario. She is the author of Violence Against Women in Early Modern Performance and coeditor, with D.J. Hopkins and Shelley Orr, of Performance and the City, both from Palgrave (2009). 
<Levin/Solga desnotes T203>

There are 6 images for this article, all keyed in to the text.

Figure 1. MT3

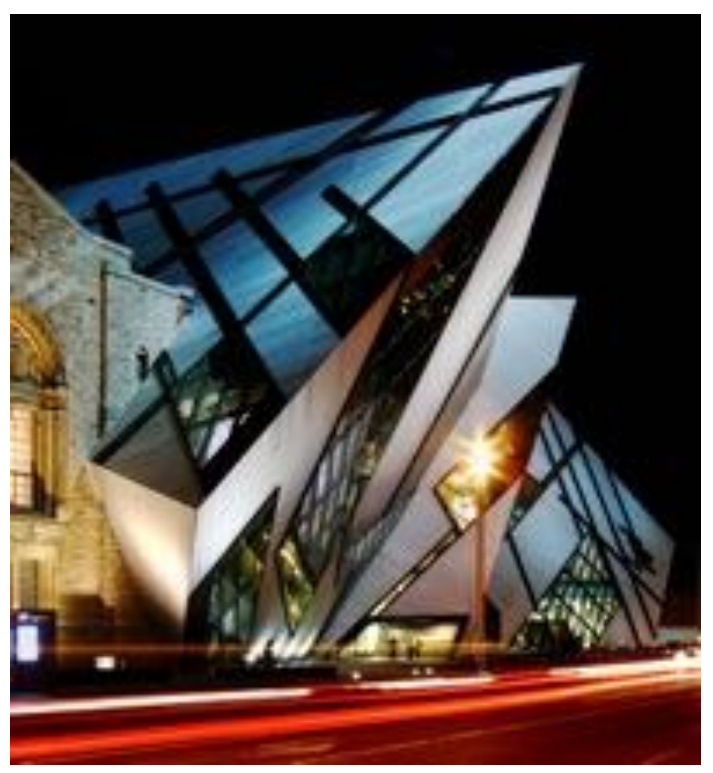

Figure 2: x19p wrap

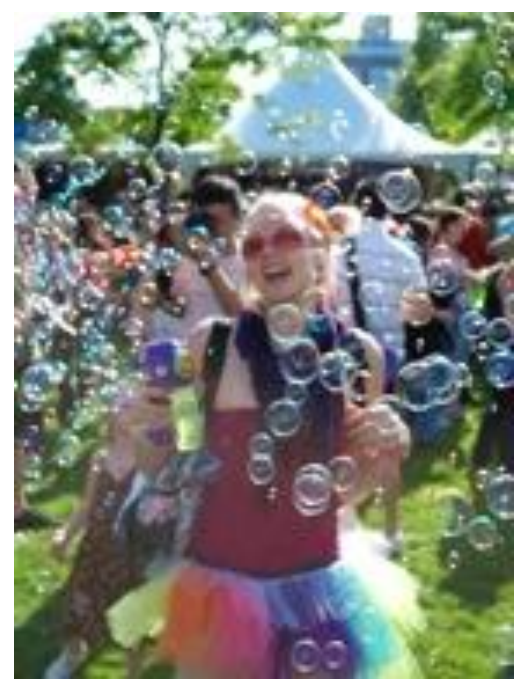


convertdoc. input. 658032 .ajzHd 47

Figure 3: x19p wrap

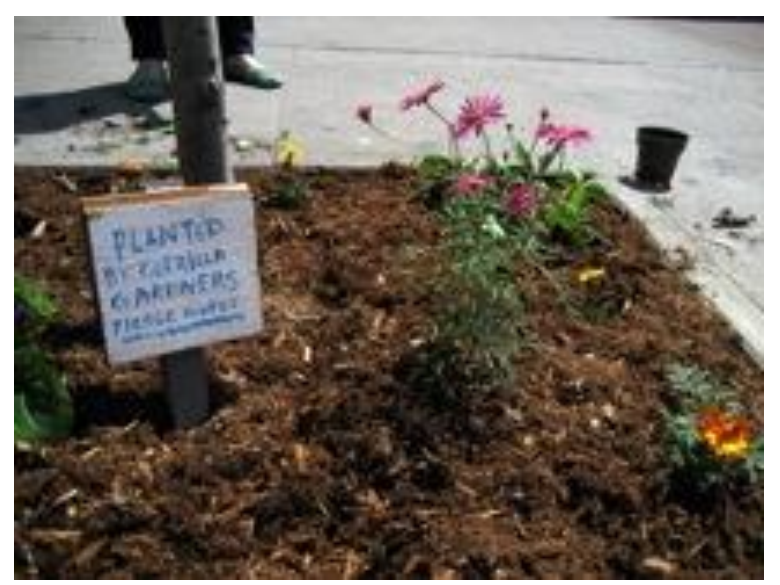

Figure 4: x30p6

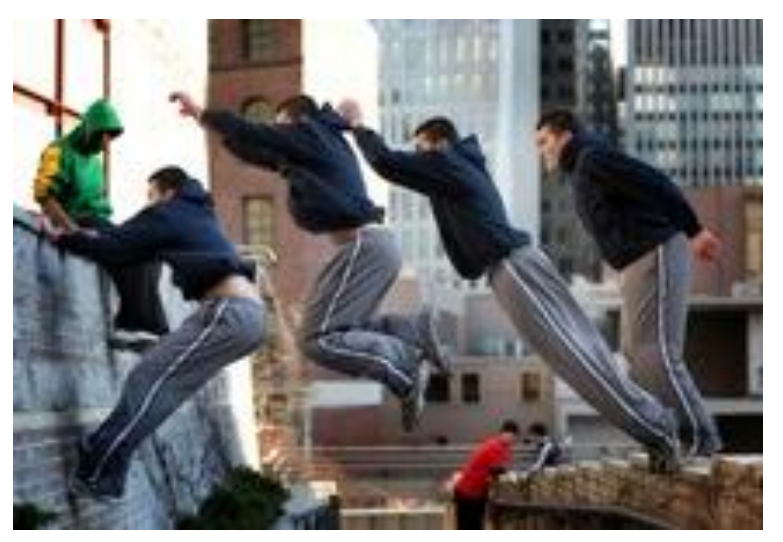

Figure 5: x19 wrap

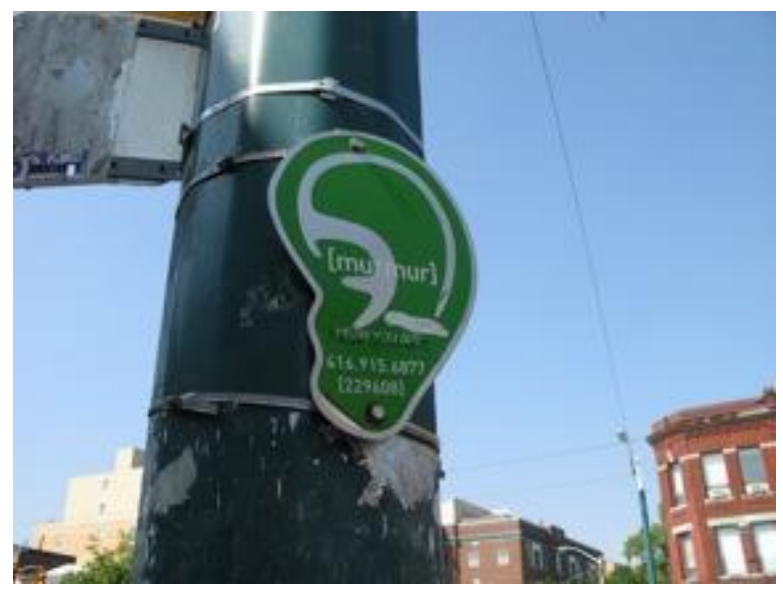


Figure 6: x30p6

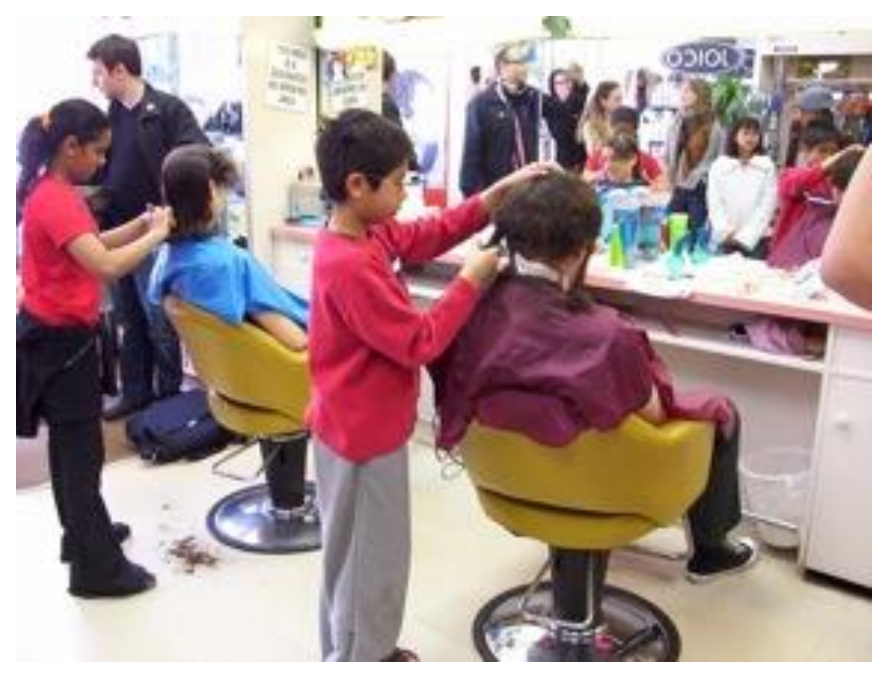

1. The Royal Ontario Museum, designed by Daniel Libeskind. (Photo by John Potter)

2. Lori Kufner, cofounder of Newmindspace, participating in the Newmindspace Bubble Battle at Toronto's Harbourfront Centre. This event was part of the Luminat'eau: Carnival H2O program at the 2008 Luminato Festival. (Photo by Scott Snider)

3. A Guerilla Gardening Project in Toronto by TPSC (Toronto Public Space Committee) and LEAF (Local Enhancement and Appreciation of Forests) completed during a Tree Triage Workshop, 2007. (Photo by Erin Leah Pryde)

4. Chris Linhares of the Parkour Toronto Group in the cloud Gardens Park in downtown Toronto, February 2006. (Photo by Miles Storey)

5. A Project Murmur sign on Toronto's Spadina Avenue. (Photo by Shira Golding, wWW.shirari.com)

6. Kids at work at the Camille Unisex Beauty Lounge on Queen st. 
West in Parkdale. Mammalian Diving Reflex's Haircuts by Children, 2006. (Photo by Nadia Halim) 